\title{
Case Studies in Agribusiness: An Interview with Ray Goldberg
}

\author{
T. Grandon Gill \\ University of South Florida, Tampa, FL, USA
}

\author{
grandon@usf.edu
}

\begin{abstract}
Agribusiness refers to the collection global systems involved in the production, distribution and consumption of food and fiber. Since the term was first coined by Harvard Business School (HBS) professors Ray Goldberg and John Davis in the 1950s, case studies have played a pivotal role in the development of the field.

In this interview with Ray Goldberg, the impact of case studies on agribusiness thought and education are discussed. Highlights include how cases have served to define the field as an area of research, provided a means of communications between researchers and practicing executives, fostered communication between executives participating in different parts of the overall systems, and, most importantly, helped students to acquire a grasp of the complex relationships between agricultural products, trade, technology, and public policy.
\end{abstract}

Keywords: agribusiness, informing systems, commodity systems, value chain, public policy, case studies, executive education, food, fiber.

\section{Introduction}

In a recent article published in Harvard Business School Alumni Bulletin titled "What's the Big Idea?" (Emmons, Hanna, \& Thompson, 2012), a timeline was presented highlighting the 20 of the most significant advances in the 100 year history of the school. Among these landmarks - which included such luminaries as Mayo's pioneering industrial research, Porter's work on strategy, Jensen's agency theory, and Christensen's disruptive innovation-was listed the 1957 publication of $A$ Concept of Agribusiness by Ray Goldberg and John Davis. This work not only coined the term agribusiness, it also introduced the concept of viewing the production, distribution, and consumption of food and fiber as a commodity system - a forerunner to today's value chain and supply chain analysis.

Material published as part of this publication, either on-line or in print, is copyrighted by the Informing Science Institute. Permission to make digital or paper copy of part or all of these works for personal or classroom use is granted without fee provided that the copies are not made or distributed for profit or commercial advantage AND that copies 1) bear this notice in full and 2) give the full citation on the first page. It is permissible to abstract these works so long as credit is given. To copy in all other cases or to republish or to post on a server or to redistribute to lists requires specific permission and payment of a fee. Contact Publisher@InformingScience.org to request redistribution permission.
In addition to being a co-inventor of the field of agribusiness, Ray A. Goldberg (George M. Moffett Professor of Agriculture and Business, Emeritus at HBS) holds another important distinction. According to his HBS web page, he has authored and supervised the development of over 1000 case studies on various private, public, and farm cooperative firms and institutions in the global food system. Informally, at least, that 
makes him the most prolific producer of business discussion cases in the history of HBS (and, quite possibly, in the world).

Still active, Goldberg continues to write and teach. Most recently, this teaching has included seminars at Harvard's Kennedy School of Government, an undergraduate course at Harvard College, and an executive agribusiness seminar conducted by HBS. Because of the extraordinary impact of he has had on the agribusiness field, and the important role that case studies have played over the course of his career, he seemed like the idea person to speak to about the manner in which case studies can be used for informing.

\section{Protocol}

The interview that follows was conducted by the author on 24 October 2012. Prior to the interview, Goldberg was sent the list of questions. The interview itself was then recorded, and an initial transcription was made using Dragon System's Naturally Speaking software. This transcript was then cleaned up by the author, and sent back to Goldberg for his approval and minor edits. A similar round of draft and approval was followed for the paper as a whole, prior to publication.

\section{The Interview}

\section{Q1. When did you develop your interest in agribusiness?}

I grew up in Fargo, North Dakota, the son of person who had a farm, developed a grain business and a seed and feed business in the Red River Valley. I was the youngest of four children and the only boy so I spent a great deal of time with my father and I developed my interest and love and appreciation for agriculture at a very young age. I remember going to work when I was 10 years old and have worked in the field of agriculture ever since. So I started at a very young age and that interest was always reinforced, not only by my immediate family, but also by everyone I ever met in my academic and business career.

Q2. So perhaps you can tell me where the term agribusiness came from?

John Davis and I spent many hours trying to figure out what we should call the food system domestically and globally. Because both of us were trained as $\mathrm{PhDs}$ in agricultural economics, we recognized that agricultural economics cannot cover the business world, that the farmer was just as much a businessman as anybody else, and that we really should encompass the whole valueadded chain. So we decided that we had better put business into the title-so we called it agribusiness.

Q3. The idea of a commodity system keeps cropping up in agribusiness. Could you explain what it means and how it relates to today's widely used concepts of supply chains and value chains?

Yes, I'd be happy to address that question, but to address it properly I have to explain what a concept of agribusiness includes and why a commodity system became important to that concept. When Davis and I wrote the book A Concept of Agribusiness (1958), we had to say "What do we include in agribusiness?" and consequently we had to look at the whole value-added chain from input supplier to farmer, to assembler, to processor, to distributor, to consumer, and we had to look at it both domestically and globally. We also had to include the subsistence farm as well as the commercial farmer because they were an integral part of the whole system. In the process of doing that we used Wassily Leontiev's input-output system to measure what those inputs were and what those outputs were so people had a visual perception of what a total agribusiness system looked like. 
Because we measured agribusiness in terms of the functions performed in the agribusiness system we recognized that the system itself was a natural system depending upon the crop cycle and the estrous cycle of plants and animals. Each commodity system was impacted by the unique characteristics of those commodities and, eventually, by the end products consumed from those specific commodities. The organizations of each of those commodity systems were developed by different kinds of institutions within those systems. So, to apply a concept of agribusiness to particular private, public, or not-for-profit entity, you had to position yourself in the commodity system in order to understand your role in it, how the system had to be changed, how you changed it, and how it changed you. I wrote a book called Agribusiness Coordination: A Systems Approach to the Wheat, Soybean, and Florida Orange Economies (1968) and I used wheat, soybeans, and citruswith the end products of bread, margarine, and frozen concentrate - to illustrate how each firm positioned themselves and how, in turn, they responded to the needs of the ultimate consumer. That made the concept of agribusiness not just a measuring of something but a concept that could be used by people that accounted for the unique characteristics of the commodities they were involved in.

\section{Q4. What role have case studies played in influencing your thinking about agribusiness?}

Because the concept of agribusiness was developed at a business school and because we teach by the case method, we had to be able to demonstrate that one could understand conceptually and operationally what agribusiness was all about using the main teaching device traditionally employed at a business school. Secondly, because we felt - conceptually and operationally - the private, public, and not-for-profit sectors all had to think as systemic managers, we had to provide cases for each of those component parts at each level of the system for them to understand not only how they fit in but also how they related to every other sector of that commodity system. So the cases became critical part only not only of our teaching objectives but of our research objectives. From there the publications that we did related to specific commodity systems and specific institutions. For example, I did a major study on the corn system of Southeast Asia. I did it in cooperation with other colleagues here and with colleagues in Asia. We had a major seminar in Japan to discuss the results of it. We had a major publication of a book-with my research assistants as co-authors - that included a lot of research but also a lot of cases applying research to the decision. So I never thought of cases being something separate from research but rather an integral part of it. I also thought cases were an integral part of the classroom experience.

Q5. It is generally acknowledged that you've written or supervised the writing of more discussion case studies than anyone in the history of Harvard Business School. Why did you need so many?

There were two major driving forces that caused me to write as many cases as I did. The major reason for writing so many cases is that we've had many different kinds of revolutions in our food systems. To capture these revolutions - whether they were the genetic revolution or some other scientific revolution, or major functional changing in operations, or the inclusion of different countries or different commodities - one could never really stop doing research without writing new cases because the two were intertwined with one another. So having a fast-changing industry - I think faster than any other industry I know of - caused me to write cases to reflect that change.

The second driving force was that in 1961 I was asked to create a senior management seminar program that could encompass the whole agribusiness global system for senior managers who wanted to come back and rethink their private, public, or NGO operations. Having taught the first seminar, I realized that the next seminar was going to include many of the people who came to the first seminar. I said to myself it's impossible to invite these people without giving them all brand-new material. So having a new senior management seminar each year since 1961 required the writing of 12 new cases every year. Secondly, the MBA course at Harvard Business School 
was a 32 day course, so I had 32 cases every year and of that 32, 12 of them were brand-new every year. So the MBA students were the beneficiaries of a demand caused by the senior management program at Harvard Business School.

\section{Q6. Why would an organization want to have the case written about it?}

Most companies don't have time to sit back and look at themselves in the mirror as much as they would like to do. So... they rely on consultants and others to help rethink who they are or what they're doing. They also began to realize that they had to constantly improve the management of their firms (or institutions or governments) and that they had to create not just educational programs outside of the companies or institutions, but that they also had to create these programs inside. To do that they needed teaching materials that were relevant to the people in that program. Therefore they were very anxious to have case studies done by them. These case materials not only enabled them to help new leaders coming into their firm, but were also used for people in their firm that they wanted to renew. This is true of the private sector, it is equally true of the public sector, and it is equally true of the NGO sector.

Q7. Who generally learns more from the case writing process, the researcher or the organization being researched?

I think it's a mutual situation. I think the researcher and the professor using the case obviously learn great deal from being able to get inside a company, understand its priority system, understand its functions, understand its value system I think the company gets an impartial look at themselves and gets that look not only from a business perspective but from a public perspective, from a consumer perspective, and from a consumer activist perspective that they rarely get any other form.

Q8. You mentioned the executive seminar. Could you tell us more about the executive seminarwho attends it and why?

When we first started out the executive seminar, the people who were the original attendees were people from the whole vertical value-added chain from farm inputs to retailers and everything in between. The reason they all came? It's the only place where the whole system is looked at. So many of these people go to horizontal programs for retailers, horizontal programs for processors, horizontal programs for farmers, horizontal programs for technology companies, etc. This is one of the few places that looks at the whole system, so that became very important.

The second thing is that the globalization of our system is such that an understanding requires global participants. Consequently having a program that attracts managers from private, public, and NGO sectors from around the world give it a global significance that keeps people coming back.

Finally, there is the fact that they can have interaction with so many different leaders of the food system in one place, at one time, in an informal setting. They get broken down into discussion groups where get to know each other in depth. This is a rare opportunity for managers in this very busy world of ours.

Q9. When you develop new cases, is it common to have the protagonist-the central figures of the case - sit in on the initial discussions?

I think it's critical to have the decision-maker in the case sit in when you teach it the very first time. No matter how well you write a case, you always may leave out something that's critical that neither you nor the decision-maker at the time of the case thought was that important. When you start discussing it the students - whether they are other senior managers, MBA students, public policy students or something else-will find issues, problems and misunderstandings in the 
case that really need to be corrected. So when you first teach a case, it's critical to have that decision-maker there.

From my own teaching experience I feel that the world is changing so much that even though the case is brand-new, it's still old compared to the time you teach it. To have that decision-maker in the case at the end of the period gives the student an opportunity to understand where that decision-maker was coming from and what his or her value system was. I think that's extremely valuable to the student. It also is valuable to the decision-makers because they're looking at the next generation of young men and women and they want to know where they are coming from. So it's important - if you possibly can - to get that decision-maker in the classroom. I feel very grateful that over my lifetime so many of them have been nice enough to make the special effort to come to class.

Q10. Do you have any examples of decision-makers who have actually rethought their decisions as a result of sitting in on a class discussion?

Yes - actually many times, not just a few. The reason being the feedback; what people they're saying in a case and what other people perceive from the case can be quite different. Given a world where there is so much distrust (unfortunately), it's important for men and women to understand how people perceive them. Even when a case is fairly written and even with the case describes a situation accurately, there are always misconceptions of what you mean, no matter how well you think you have articulated it or how well the case writer has written it.

We live in a world where trust is the most important factor for any company, public entity or any NGO institution. The mistrust in our world today is so great - and the importance of food, health, science and development is more recognized than ever today - that you cannot afford to have a document that can be misconstrued to the point where people actually reading the case distrust you because of what you inadvertently said that may seem innocent.

Q11. Do you have any specific examples of where the decision-maker going into the discussion thought "I'm going to do XYZ" and then after the discussions said: "No. After thinking about it I'm going to do $A B C$ ?"

Yes, I have many examples of that, especially when the case is about a new conceptual framework, a new way of approaching health, or development, or nutrition, or a new way of approaching partnering in a system. They come back sometimes and say, "I'm going to change based on this discussion". In addition to that, everything is off the record in our classroom. Nobody takes notes on the person discussing the case from the company or whatever institution it may be. We have brownbag lunches after cases where we just talk as people. In many of those conversations, they will say to the students, "You know, you made a good point". That discussion could even be outside the classroom as well as inside. So I think we have men and women in industry who appreciate constructive criticism and constructive ideas. And that is why they are successful.

Q12. Stepping back for a moment, there is a common conception - at least outside of HBS - that discussion cases are not really research. In your own mind, what difference (if any) exists between discussion and research cases?

I can't speak for other faculty members or other kinds of courses either here at Harvard or anywhere else. I have never supervised or written a case study that wasn't futuristic. I believe that the best way to learn is not just to look at the past but to force the student to think futuristically. So if one is going to think futuristically, you have to have enough material in case to give them trends and alternatives that are researchable, or have been partially researched in the case itself. I feel very strongly that anybody writing a case and thinking of it in past terms is doing the student a disservice. We're here to train young (and older) men and women to think futuristically and a case study is an attempt to do that both operationally and in terms of research. 
My cases have been accused of being much too long. I've tried to satisfy people by shortening those cases - but then I also create a technical note to go along with the case (so there's enough researchable material for the student to look at that technical note and the relate it back to case). We're going through metamorphosis here at the Harvard Business School in terms of case length. We want to keep them shorter and shorter and shorter. Frankly, I find that those cases don't work very well in something as broad as agribusiness.

They are also doing something else that I find not so good. They are taking older cases, disguising them, trying to use the same concepts, and then pretending that they are new cases. I find that very disagreeable to my way of looking at things. I feel you have to have the real case, the real future, the real decision-maker, not something from a superficial look back that reinvents the case. I believe we have to use our resources to make sure that those cases are futuristic. I try to pick cases not just about the subject matter, but about the decision-maker himself or herself. If we don't pick cases about the change-makers in our society, we're not doing a good job in terms of teaching. I believe very strongly in picking cases where the cases are not only important, but where the decision-maker in the case is important. Part of the reason for wanting the decisionmaker to be present is not just to correct mistakes but to enable the students to realize that, at the end of the day, the decision-maker is actually even more important than the case.

Q13. What role do you feel that agribusiness research has had on business practice? Have cases played a role in changing business practice?

I think that agribusiness research-by the very nature of it being global, being inclusive in terms of looking at the system itself-has forced decision-makers to re-examine where their system is going, how it is changing them, and how they are changing it. I think also the biggest change that Dean [Donald] David really wanted was not only to teach a systemic approach to the food system. He was worried, even then (back in 1955), about the distrust that exists in all parts of the food system. He was worried that the farmer didn't trust the processor and didn't trust the scientific technology. And the consumer didn't trust anybody. He felt there had to be a better way of getting people to begin to understand each other.

Two things have occurred in my lifetime for which I am grateful. One, because of consolidation and the growing importance of food and nutrition, food companies increasingly have pharmaceutical divisions to test the relationship of food to people's nutrition and health. I think that people are beginning to partner both vertically and horizontally much more than they did before. They are beginning to think longer term with one another strategically, so that it isn't just I win and you lose, it isn't just a transactional relationship. There is a natural tension between buyer and seller but now, even with that tension, they work out together their future plans. They now work out together the kinds of things they can do improve life for the consumer they both serve. So I think that's become very important.

The other thing that I've done is to create a university-wide center with the business school, the [Harvard] Kennedy School [of Government], the School of Public Health, the Medical School and the Biochemistry Department. The kinds of problems I deal with are multidisciplinary; they are not just business school problems any more. And now we have so many more joint degrees for that very reason. So from my perspective, I think agribusiness has enabled people to see how they can work together. We now have more private-public partnerships in research in the food system than we have ever had before. We now have companies such as Monsanto and DuPont working with the Rockefeller Foundation and the Ford Foundation on developing technologies. Sometimes, they're even afraid to admit they are working together for fear they will be accused of giving in to the business community. But, in spite of that fear, these private-public partnerships are working. 
To get back to your original question, I think that we have changed how we do research, who we do research with, and how we impact the thinking of the people in the food system - to their betterment and to our (academic) betterment.

Q14. Over the years you have had thousands, actually tens of thousands, of students. How do you decide if they are learning something valuable from your cases and the discussions?

It is difficult to measure because you would need feedback on people who are so busy that they don't have time to give you feedback. But I think that the feedback that I have had has been very gratifying to me. Many of the students who took agribusiness while they were here took the course not because they wanted to learn agribusiness per se, but because it was the one place where they could take [what they learned in] every other course and apply it to a major industry in the world [i.e., the global agribusiness system]. That enabled them to see how all these different functional operations that they were looking at fit together. That gave them a way of looking at any system you see that in the newspapers today - the food chain of the automobile industry, the food chain of the energy industry. They see that understanding the system that transforms a germ plasm of wheat into a loaf of bread can help them understand any system.

The other thing that makes me feel so good about it is that-because I still teach in our senior management program (that is now run by my successor, professor David Bell) - I still have people come up to me to tell me how much they appreciated the case, or the approach, or the way it is taught. They didn't have to come and tell me that, and it makes me feel that they are getting something out of the conceptual frameworks that we are still using here today. The feedback that I got (and still get) from these students has enabled me to improve the cases and improve the research.

Every year, even today, I get evaluated by my students and it's important to see what they got out of the course, to see what they got out of the program. My greatest satisfaction was to teach an undergraduate course for the first time on climate and its impact on the global food system. The feedback I got from those undergraduate students was more complete, more thorough than any I ever got from any senior manager, or any MBA student. They were so ecstatic about what they learned that that I took the comments and sent them to my children. I said you don't have to write an obit about me anymore, about just use these.

Q15. From your perspective what you think is more important for a student's learning: the material in the case itself or the attendant discussion of that case?

The whole purpose of case discussion is to enable the student to develop his or her own approach to problem solving, in their manner. Being a case teacher, I believe that the discussion is the most important because, at the end of the day, the objective of teaching by the case method is not for the student to mirror the faculty member's perspective or the faculty member's approach. Instead, it is to develop their own unique approach to decision-making, to use their own way of approaching a problem so that they become a better educated person - and have more self-confidence in their ability to create a model in their mind of how to tackle these problems and do it in a creative way.

Q16. When you're discussing a case does it matter if your students are MBA candidates or executives?

It matters in the sense that the MBA students have a different background and a different perception of what the decision-maker is looking at than the senior managers. The senior managers tend to look at a case and relate it to their specific business or their specific commodity system and transfer that back to the case; to think of the global food system from their operating perspective. The graduate students tend to do two things. They look at the case and they position themselves as the decision-maker but they are less inhibited by all of the things that they have encountered in 
the past that have forced them to "not do" some of the things they would have really liked to do. They are more free-spirited in terms of how they view the world.

I notice that now we are admitting younger students in our MBA program. We purposely do that because of that free-spirited perspective that they bring to the classroom. They don't have a particular frame of reference that forces them not to think of something unusual, not to think of something quite different than anybody else in that room. So we let their mind become, in some respects, more creative than the people who had more experience.

Q17. After all this time, do you still feel that you learn something when one of your cases is discussed?

Yes, I feel that I always learn something new every time one of my cases is discussed. Years ago I had two sections of MBA students. The first class I taught was so different from the second class that I taught you would think we had a different case study. The people in that room, their unique creativity, their unique way of approaching a problem, makes everyone in that roomincluding the professor - think very differently than any other time that case has been taught.

Q18. Finally, you started teaching at HBS in the 1950s and you are still active. What is it about this job that keeps you going?

There are several things that keep me going. First, the industry itself is still changing at an even faster rate than at any other time in my life. I feel that a book that is long overdue needs to be finished and I want that "one more case" to be in that book to make sure it's relevant at the moment I stop writing it.

The second thing that keeps me going is that I enjoy working with men and women who are trying to do a better job in making this food system more responsive to the priorities of our society. I feel that the recognition of the importance of this industry, and the multi-discipline nature of it, is such that I keep learning more every day than I ever dreamed possible to learn... and I realize there's that much more to learn. I'm grateful that I have enough health, enough brainpower, to enable me to keep going. As long as I have those abilities, and as long as students get something out of it, I'd like to continue.

\section{Conclusions}

A central motivation for the special series on The Role of Case Studies in Informing Systems was to help us better understand the versatility of the discussion case. Of particular interest has been the ability of the discussion case to enable informing flows within and between the worlds of students, researchers and practice, as illustrated in Figure 1.

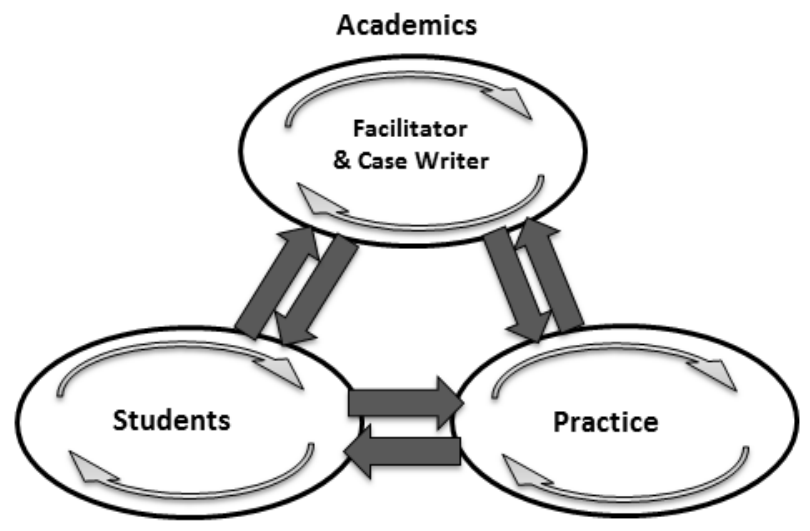

Figure 1: Potential informing flows between research, students and practice 
Examples of each of these informing flows among faculty, students, and practice may be found in the interview with Ray Goldberg, as shown in the $3 \times 3$ matrix in Table 1.

Table 1. Examples of Informing Flows in Capstone Course

\begin{tabular}{|c|c|c|c|}
\hline From: & Faculty & $\begin{array}{c}\text { To: } \\
\text { Students }\end{array}$ & Practice \\
\hline Faculty & $\begin{array}{l}\text { Diffusion of agribusiness } \\
\text { concepts into other re- } \\
\text { search areas (Q3). } \\
\text { Extensive use of case stud- } \\
\text { ies in the agribusiness re- } \\
\text { search stream (Q4). } \\
\text { Importance of authenticity } \\
\text { of agribusiness cases } \\
\text { (Q12). } \\
\text { Use of cases in multi- } \\
\text { disciplinary research } \\
\text { (Q13). }\end{array}$ & $\begin{array}{l}\text { Learning that occurs dur- } \\
\text { ing classroom discus- } \\
\text { sions of each case (Q14). }\end{array}$ & $\begin{array}{l}\text { Success of executive agri- } \\
\text { business management } \\
\text { seminar (Q5). } \\
\text { Engagement in the case } \\
\text { writing process (Q6 and } \\
\text { Q7). } \\
\text { Knowledge acquired from } \\
\text { cases that are the basis of } \\
\text { the agribusiness research } \\
\text { stream (Q13). }\end{array}$ \\
\hline Students & $\begin{array}{l}\text { Feedback from students on } \\
\text { what they are learning } \\
\text { (Q14). } \\
\text { What instructor learns } \\
\text { each time the case is dis- } \\
\text { cussed (Q17) }\end{array}$ & $\begin{array}{l}\text { Importance of peer-to- } \\
\text { peer discussion in the } \\
\text { informing process (Q15) }\end{array}$ & $\begin{array}{l}\text { Insights gained from sitting } \\
\text { in on classroom discussion } \\
\text { and follow-up discussions } \\
\text { (Q9, Q10 and Q11). }\end{array}$ \\
\hline Practice & $\begin{array}{l}\text { Mutual learning during } \\
\text { case writing process (Q7 } \\
\text { and Q18). }\end{array}$ & $\begin{array}{l}\text { Involvement of protago- } \\
\text { nist in initial classroom } \\
\text { discussions (Q9). } \\
\text { Follow-up discussions } \\
\text { outside the classroom } \\
\text { (Q11). }\end{array}$ & $\begin{array}{l}\text { Role of case discussions in } \\
\text { the agribusiness executive } \\
\text { seminars (Q8). }\end{array}$ \\
\hline
\end{tabular}

The table offers some interesting departures from some of the more dominant approaches to education and research used in business and the social sciences. On the education side, the traditional lecture approach emphasizes the one-way instructor-to-student informing pathway. In stark contrast, the case method described by Goldberg emphasizes interactive channels between students, students and instructors, and - in situations where the protagonist sits in on the discussionbetween students and the protagonist. The only real area of uncertainty seems to be which of these groups typically learns the most during the process. Traditional educational models tend to encourage matching content to the students' pre-existing levels of knowledge and experience. In Goldberg's approach, the same case may serve undergraduate, graduate and even executive students. The nature and content of the discussion is likely to vary across these groups; each can learn from the case, however.

On the research side, the published refereed journal article (the gold standard for academic research in business, education, and many of the social sciences) represents a one-way pathway from one researcher (or small group of co-authors) to an audience consisting mainly of the broader collection of scholars within the discipline or specialty. Typically, the focus is on present- 
ing new theory or tests of theory - abstractions that are not particularly time sensitive upon which later research can be built. The distinction between what constitutes research (e.g., the article) and its later use in teaching (e.g., how it may be presented in a textbook) is crystal clear.

Goldberg's description of the use of cases in agribusiness research suggests a very different philosophy. To begin with, by insisting that discussion cases be both authentic and detailed (see his response to Q12), the line between research and pedagogy becomes blurred. The same case study that is used for classroom discussion may also prove suitable for use as an observation in later research. The discussion of a case may be used as a means of bringing diverse research disciplines to a common understanding of a problem (see Q13), an important element of any multidisciplinary research effort. The decision-maker focus that he describes (in Q12) implies an objective of research that is less likely to be focused on finding enduring and general prescriptive or descriptive rules (i.e., theory) and more likely to emphasize developing flexible approaches to problem solving. He further believes that rapidly changing environments mean these approaches need to be continually updated with a new stream of cases. Finally, and perhaps most critically, Goldberg sees the intended audience for his research efforts to consist of scholars, students and practitioners. Rather than hoping that some theory he proposes may eventually wend its way to practice (perhaps through inclusion in some textbook), the approach he describes virtually guarantees immediate impact - at least upon the participants in the case itself.

\section{References}

Davis, J. H., \& Goldberg, R. A. (1958). A concept of agribusiness. Graduate School of Business Administration, Harvard University.

Emmons, G., Hanna, J. and Thompson, R. (2012). What's the big idea? HBS Alumni Bulletin, September, 88(3), 35-39.

Goldberg, R. A. (1968). Agribusiness coordination: A systems approach to the wheat, soybean, and florida orange economies. Harvard Business School.

\section{Biography}

Grandon Gill is a Professor in the Information Systems and Decision Sciences department at the

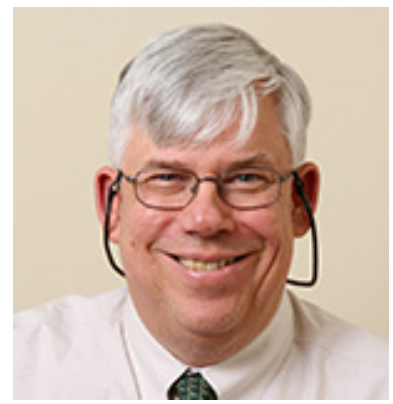
University of South Florida. He holds a doctorate in Management Information Systems from Harvard Business School, where he also received his M.B.A. His principal research areas are the impacts of complexity on decision-making and IS education, and he has published many articles describing how technologies and innovative pedagogies can be combined to increase the effectiveness of teaching across a broad range of IS topics. Currently, he is Editor-inChief of Informing Science: The International Journal of an Emerging Transdiscipline and an Editor of the Journal of IT Education. 